Doi: $10.4274 /$ vhd.69775

Viral Hepatitis Journal 2014; 20(3): 131-133

\title{
Treatment of Hepatocellular Cancer Due to Hepatitis Delta with Yttrium-90 Radioembolization in a Patient with Cirrhosis: A Case Report
}

\author{
Delta Hepatitine Bağı Sirozlu Hastada Hepatosellüler Kanserin Yttrium-90 ile \\ Radyoembolizasyon Tedavisi: Olgu Sunumu
}

\author{
Ahmet UYANIKOĞLU1, Filiz AKYÜZ2, Fatih ERMIŞ3, Sabahattin KAYMAKOĞLU2 \\ ${ }^{1}$ Harran University Faculty of Medicine, Department of Gastroenterology, Şanlıurfa, Turkey \\ 2 Istanbul University Istanbul Faculty of Medicine, Department of Gastroenterology, Istanbul, Turkey \\ ${ }^{3}$ Düzce University Faculty of Medicine, Department of Gastroenterology, Düzce, Turkey
}

\begin{abstract}
Cirrhosis due to delta hepatitis is one of the most important etiologic factors in our country. Hepatocellular carcinoma (HCC) often develops on the base of cirrhosis. Recently, yttrium-90 radioembolization therapy has been increasingly used in the treatment of HCC. Transarterial infusion of yttrium-90 radioactive microspheres is a new promising method in treating unresectable liver tumors. Herein, we present a 55-year-old male HCC patient who developed HCC due cirrhosis associated with delta hepatitis and was successfully treated with yttrium-90 radioembolization therapy. (Viral Hepatitis Journal 2014; 20(3): 131-133)
\end{abstract}

Key words: Hepatocellular cancer, yttrium-90

Conflict of interest: The authors reported no conflict of interest related to this article.
ÖZET

Ülkemizde sirozun önemli etyolojik nedenlerinden biri delta hepatitidir. Hepatosellür kanser (HSK) sıkıkla siroz zemininde gelişmektedir. HSK tedavisinde radyoembolizasyon olarak adlandırılan yttrium-90 tedavisi son yıllarda gittikçe daha yaygın kullanılmaktadır. Radyoaktif mikropartiküllerin transarteryal olarak infüze edilmesinden oluşan ve daha yeni bir yöntem olan radyoembolizasyonun rezeke edilemeyen karaciğer tümörlerinde umut vaat ettiği bildirilmiştir. Delta hepatitine bağı kompanse karaciğer sirozu zemininde HSK gelişen ve yttrium-90 ile başarıı kemoembolizasyonu yapılan 55 yaşında erkek hasta sunulmuştur. (Viral Hepatit Dergisi 2014; 20(3): 131-133)

Anahtar kelimeler: Hepatosellüler kanser, yttrium-90

Çıkar çatışması: Yazarlar bu makale ile ilgili olarak herhangi bir çıkar çatışması bildirmemişlerdir.

\section{Introduction}

Hepatocellular carcinoma ( $\mathrm{HCC}$ ) is one of the most widely seen malignities in the world; it constitutes $90 \%$ of liver cancers and its incidence is still increasing. Its curative treatments are surgical resection and liver transplantation, but many patients lose their chance of surgery for being at an advanced stage. Its palliative treatments include radiofrequency ablation therapy, transarterial chemoembolization, chemotherapy and radiotherapy (1).

Cirrhosis associated with hepatitis $B$ virus (HBV) infection is still one of the major risk factors in developing HCC. In Turkey, HCC is hardly diagnosed at an early stage $(2,3)$. Hepatitis delta virus (HDV) infection increases the risk for HCC 3 times, and for mortality, 2 times (4). Our country is moderately endemic in terms of HBV and the prevalence of HDV is around 5\%. Chronic delta hepatitis is difficult to treat and is one of the major etiologic reasons of cirrhosis and HCC in our country $(5,6,7)$.

Besides transarterial chemoembolization (TACE), yttrium-90 therapy (Y90), which is defined as transarterial radioembolization (TARE), is being used increasingly in recent years to treat HCC. It has been also reported that radiation lobectomy using $\mathrm{Y} 90$ is an effective and safe technique for the hypertrophy of the remaining 
part of the liver and this new technique can be used as a bridge to resection and transplantation $(8,9)$.

This procedure is named as radioembolization and has two separate stages: the first one is the injection of embolic particles as a medium (embolization) and the administration of radiation from this medium (radio). The procedure involves transarterial administration of radioisotope loaded micron-sized particles. Emergence of complications is rare, but nausea, weakness, abdominal pain, hepatic failure, biliary damage, fibrosis, radiation pneumonia, gastrointestinal ulcers, and vascular damage may be seen. These side effects can be prevented by a meticulous evaluation before the treatment, careful selection of patients and adequate dosimetry (10).

A 55-year-old male patient who was diagnosed with $\mathrm{HCC}$ on the basis of compensated liver cirrhosis associated with delta hepatitis was administered radioembolization with Y90.

\section{Case}

The patient had been known to have a positive HBsAg for a long time, but had not been monitored regularly. $\mathrm{HCC}$ indicating lesions of $2 \mathrm{~cm}$ in the cirrhotic segment 7 and $6 \mathrm{~cm}$ in segment 6 of the liver were detected by abdominal magnetic resonance imaging (MRI) during his examinations in November 2008. The patient had positive HBsAg and anti-delta and negative HBV-DNA and HDVRNA. He was hospitalized to be assessed for transplantation.

On physical examination, there was no hepatomegalia, Traube's space was open and there was no acid. His tests revealed

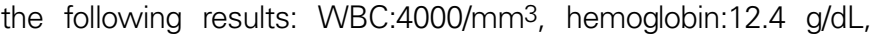
hematocrit: $35.8 \%$, thrombocyte: $105000 / \mathrm{mm}^{3}$, glucose: $111 \mathrm{mg} /$ dL, BUN: 16 mg/dL, creatinine: 0.7 mg/dl, ALP: 290 U/L, GGT: 95 U/L, AST: 43 U/L, ALT: 48 U/L, LDH: 325 U/L, Tbil: 0.47 mg/dL, PT: $15.2 \mathrm{sec}$ and AFP: $14 \mathrm{ng} / \mathrm{mL}$.

100-300 micron drug eluting microspheres loaded with 50 mg doxorubicin was injected through his distal cystic artery into his right hepatic artery and polyvinyl alcohol (PVA) particles were given to the artery feeding the lump to complete the embolization procedure. Following the procedure, he had a fever of up to $39{ }^{\circ} \mathrm{C}$ during his monitoring, but his overall condition did not get worse. His hemodynamic parameters remained stable, his highest CRP value reached $114 \mathrm{mg} / \mathrm{dL}$ (normal less than $0.1 \mathrm{mg} / \mathrm{dL}$ ) and, there was no growth in his hemocultures and urine cultures. No abdominal sensitivity or pain in his upper right quadrant was detected on his physical examination. His abdominal ultrasonography revealed changes in his liver due to radioembolization, but there were no signs suggesting any septic complication. When empirical ampicilinesulbactam $4 \times 1 \mathrm{~g}$ and paracetamol tablet $4 \times 1$ were started, his fever went down and CRP values declined. At post-embolization day 14 , his unenhanced abdominal computed tomography was taken to assess the effectiveness of the procedure. Necrosis and air were seen in the lesion and the procedure was accepted to be successful. He was then discharged after deciding that his antibiotic treatment was to be completed orally through 3 weeks. It was planned to reassess the patient for transplantation based on his results by taking his MRI 3 months later.

\section{Discussion}

Chronic infection associated with delta virus is a risk factor for cirrhosis and HCC. High HDV viremia increases the risk of developing cirrhosis and HCC. A HDV replication is a predictor for poor prognosis in a patient developing cirrhosis (11). A persistent HDV replication causes cirrhosis and $\mathrm{HCC}$ at annual rates of $4 \%$ and $2.4 \%$, respectively; and it is the only predictor for liver mortality (12). In our patient, cirrhosis and HCC developed due to delta hepatitis. Although the patient had been known to be HBsAgpositive for a long time, anti-delta was detected just recently. His HBV-DNA and HDV-RNA was found to be negative.

$\mathrm{HCC}$ is a tumor exhibiting heterogeneity depending on morphologic, biological and hepatic functions. There is a risk of recurrence and deficient treatment after TACE depending mostly on the size and multitude of the tumors in a medium stage HCC. Suppression of angiogenic stimulation after TACE may be a rational approach and radioembolization with $Y 90$ is promising for mediumstage HCC. Information on internal radiation therapy with Y90 for advance-stage HCC is still not satisfactory (13). Preoperative TARE may be an option for curative treatment for HCC patients with unresectable liver cancer and are candidates for palliative care (14). Our patient was a medium-stage patient and was administered TARE as he had no chance of having transplantation immediately.

A study made in Turkey reported that when compared to TACE, TARE caused less systemic toxicity and could be administered without hospitalization, to the advantage of both physicians and their patients. With the limited experience in the study, it was shown that TARE was a promising method in the initial-stage treatment of a liver cancer not allowing resection, however, it was also reported that there was a need for further randomized, controlled and multicenter studies (15). Another study reported low frequency of experiencing complications, including nausea, weakness, abdominal pain, hepatic failure, biliary damage, fibrosis, radiation pneumonia, gastrointestinal ulcers and vascular damage that can be prevented by meticulous evaluation before treatment, careful selection of patients and adequate dosimetry (10). Our patient, had fever, his condition did not get worse, his hemodynamic parameters remained stable and CRP levels were high. His abdominal ultrasonography revealed no signs suggesting any septic complication. When empirical ampiciline-sulbactam $4 \times 1$ $\mathrm{g}$ and paracetamol tablet $4 \times 1$ were started, his fever went down and CRP values declined.

A radical treatment following a tumor regression therapy with TARE in advanced HCC patients exceeding the UCSF/ Milan criteria may be applicable in selected subgroups (UNOS T3 stage) by also considering the other restrictive factors. The overall survival without tumors after transplantation in patients who are administered a successful regression therapy is as excellent as in patients meeting the required criteria $(16,17)$. Our patient had $\mathrm{HCC}$ indicating lesions of $2 \mathrm{~cm}$ in the cirrhotic segment $7 \mathrm{~cm}$ and $6 \mathrm{~cm}$ in segment 6 of the liver detected by MRI and he was at the limit with respect to the Milan criteria, but he had no donor for immediate transplantation. With a successful TARE, time was gained for transplantation and the procedure proved to be a bridge to a perfect transplantation. 
Patients with portal vein thrombosis (PVT) have an extremely poor prognosis and have relatively minimal treatment options. Evidences have shown that TARE is a good option for such patients. The accumulated data on Y90 radioembolization have shown that it is a potent anticancer treatment method with acceptable side effects, provided that appropriate assessments including dosimetry are employed before treatment. The combination of TARE and the molecular agents directly aiming the target exhibit a synergic effect on survival. With the Y90 TARE method, the disease is controlled at a rate more than $80 \%$ and it is generally well tolerated. It's major complication is PVT, however, this is not due to its microembolic effect but its radiation effect on untargeted tissues including the liver $(18,19,20,21)$. No PVT was detected in our patient. Despite some side effects, the procedure was successful.

In conclusion, Y90 radioembolization should be considered as a treatment option in patients with $\mathrm{HCC}$ with unresected liver cancer or in those with no chance of immediate transplantation.

\section{References}

1. Wang Z, Zhang G, Wu J, Jia M. Adjuvant therapy for hepatocellular carcinoma: current situation and prospect. Drug Discov Ther. 2013; 7(4): 137-143.

2. Özer B, Serin E, Yılmaz U, Gümürdülü $Y$, Saygıı OB, Kayaselçuk F, Boyacioğlu S. Clinicopathologic features and risk factors for hepatocellular carcinoma: Results from a single center in southern Turkey. Turk J Gastroenterol. 2003; 14(2): 85-90.

3. Uyanıkoğlu A, Coşkun M, Albayrak F, Öztürk $Y$, Tay A, Kibar Yl. Genç yaşta hepatsellüler Karsinoma lle Prezente Olan, Hepatit B'ye Bağlı Iki Karaciğer Sirozu Vakası [Two Cases with Liver Cirrhosis Secondary to Hepatitis B that Prezented with Hepatocellular at Young Age]. Dicle Tip Dergisi. 2013; 40(1): 131-133.

4. Fattovich G, Giustina G, Christensen E, Pantalena M, Zagni I, Realdi G, Schalm SW. Influence of hepatitis delta virus infection on morbidity and mortality in compensatedcirrhosis type B. The European Concerted Action on Viral Hepatitis (Eurohep). Gut. 2000; 46(3): 420-426.

5. Uyanıkoğlu A, Coşkun M, Albayrak F, Aktaş F, Binici DN, Öztürk Y. Erzurum Illi ve Çevresinde Kan Donörlerinde Hepatit B Seroprevalansı [Seroprevalance of Hepatitis B Among Healty Blood Donors in Erzurum region]. Viral Hepatit Dergisi [Viral Hepatitis Journal] 2012;18(3):91-93.

6. Uyanıkoğlu A, Aydoğan T, Nar H, Çetin B, Sert U. Şanlıurfa Yöresinde HBsAg (+) Hastaların Klinik Dağılımı ve Demografik Özellikleri. IX. Ulusal Hepatoloji Kongresi Bildiri Özetleri Kitabı. 28 Mayıs- 1 Haziran 2013, Istanbul, P-059, 141.

7. Albayrak A, Coşkun M, Uyanıkoğlu A, Bayır Y, Yılmaz H, Kibar YI, Tay A, Albayrak F. Kronik Hepatit Delta'sı Olan Hastaların Pegile Interferon Tedavi Yanıtlarının Değerlendirilmesi. Vir Hep Derg. 2012; 18(2): 68-70.

8. Ettorre GM, Laurenzi A, Vennarecci G. Downstaging Hepatocellular Carcinoma with Yttrium-90 radioembolization: Resection or transplantation? Eur J Surg Oncol. 2014; 40(6): 789-790.
9. Vouche M, Lewandowski RJ, Atassi R, Memon K, Gates VL, Ryu RK, Gaba RC, Mulcahy MF, Baker T, Sato K, Hickey R, Ganger D, Riaz A, Fryer J, Caicedo JC, Abecassis M, Kulik L, Salem R. Radiation lobectomy: time-dependent analysis of future liver remnant volume in unresectable liver cancer as a bridge to resection. J Hepatol. 2013; 59(5): 1029-1036.

10. Memon K, Lewandowski RJ, Riaz A, Salem R. Yttrium 90 microspheres for the treatment of hepatocellular carcinoma. Recent Results Cancer Res. 2013; 190: 207-224.

11. Romeo R, Foglieni B, Casazza G, Spreafico M, Colombo M, Prati D. High serum levels of HDV RNA are predictors of cirrhosis and liver cancer in patients with chronic hepatitis delta. PLoS One. 2014; 9(3): 92062.

12. Romeo R, Del Ninno E, Rumi M, Russo A, Sangiovanni $A$, de Franchis R, Ronchi G, Colombo M. A 28-year study of the course of hepatitis Delta infection: a risk factor for cirrhosis and hepatocellular carcinoma. Gastroenterology. 2009; 136(5): 1629-1638.

13. Kim do $\mathrm{Y}$, Han $\mathrm{KH}$. How to improve treatment outcomes for hepatocellular carcinoma of intermediate and advanced stage. Dig Dis. 2012; 30(6): 598-602.

14. Felga G, Evangelista AS, Salvalaggio PR, Curvelo LA, Della Guardia B, Almeida MD, Afonso RC, Ferraz-Neto BH. Clinical profile and liver explant findings in patients with and without pretransplant downstaging for hepatocellular caravcinoma. Transplant Proc. 2012; 44(8): 2399-2402.

15. Peynircioğlu B, Çil B, Bozkurt F, Aydemir E, Uğur Ö, Balkancı F. Rezeke edilemeyen karaciğer kanserinin tedavisi için radyoembolizasyon: tek bir merkezdeki ilk deneyimler. [Radioembolization for the treatment of unresectable liver cancer: initial experience at a single center]. Diagn Interv Radiol. 2010; 16: 70-78.

16. Inarrairaegui M, Pardo F, Bilbao Jl, Rotellar F, Benito A, D'Avola D, Herrero JI, Rodriguez M, Martí P, Zozaya G, Dominguez I, Quiroga J, Sangro B. Response to radioembolization with yttrium-90 resin microspheres may allow surgical treatment with curative intent and prolonged survival in previously unresectable hepatocellular carcinoma. Eur J Surg Oncol. 2012; 38(7): 594-601.

17. Yu CY, Ou HY, Huang TL, Chen TY, Tsang LL, Chen CL, Cheng YF. Hepatocellular carcinoma downstaging in liver transplantation. Transplant Proc. 2012; 44(2): 412-414.

18. Lau WY, Sangro B, Chen PJ, Cheng SQ, Chow P, Lee RC, Leung T, Han KH, Poon RT. Treatment for hepatocellular carcinoma with portal vein tumor thrombosis: the emerging role for radioembolization using yttrium-90. Oncology. 2013; 84(5): 311-318.

19. Kim YH, Kim do Y. Yttrium-90 radioembolization for hepatocellular carcinoma: what we know and what we need to know. Oncology. 2013; 84(Suppl 1): 34-39.

20. Takayasu K. Transcatheter arterial chemoembolization for unresectable hepatocellular carcinoma: recent progression and perspective. Oncology. 2013; 84(Suppl 1): 28-33.

21. Mazzaferro V, Sposito C, Bhoori S, Romito R, Chiesa C, Morosi C, Maccauro M, Marchianò A, Bongini M, Lanocita R, Civelli E, Bombardieri E, Camerini T, Spreafico C. Yttrium-90 radioembolization for intermediate-advanced hepatocellular carcinoma: a phase 2 study. Hepatology. 2013; 57(5): 18261837. 